\title{
Synthesis, Characterization and Gas Sensor Application of New Composite Based on MWCNTs:CoPc:Metal Oxide
}

\author{
Mohanad Mousa Kareem ${ }^{*}$ \\ Burak Yahya Kadem ${ }^{2}$ \\ Abbas J. Atiyah ${ }^{1}$
}

Emman J. Mohammad ${ }^{1}$

${ }^{1}$ Department of Chemistry, College of Science, University of Babylon, Hilla, Iraq
${ }^{2}$ Al-Karkh University of Science, College of Science, Haifa Street, Baghdad, Iraq
${ }^{*}$ Corresponding author: sci.mohanad.mousa@ uobabylon.edu.iq ${ }^{*}$, drburakkadem@gmail.com,
sci.abbas.jassim@ uobabylon.edu.iq , emanjassim4@gmail.com
*ORCID ID: https://orcid.org/0000-0003-4931-5524 ${ }^{*}$, https://orcid.org/0000-0001-6483-8345, https://orcid.org/0000-
0003-1798-0095 ,https://orcid.org/0000/0002-2400-3148

Received 31/3/2020, Accepted 14/6/2020, Published Online First 11/1/2021, Published 1/6/2021

\begin{abstract}
:
The synthesis of new substituted cobalt Phthalocyanine (CoPc) was carried out using starting materials Naphthalene-1,4,5, tetracarbonic acid dianhydride (NDI) employing dry process method. Metal oxides (MO) alloy of $\left(\% 60 \mathrm{Ni}_{3} \mathrm{O}_{4} \% 40-\mathrm{Co}_{3} \mathrm{O}_{4}\right)$ have been functionalized with multiwall carbon nanotubes $(\mathrm{F}-$ MWCNTs) to produce (F-MWCNTs/MO) nanocomposite (E2) and mixed with CoPc to yield (FMWCNT/CoPc/MO) (E3). These composites were investigated using different analytical and spectrophotometric methods such as ${ }^{1} \mathrm{H}-\mathrm{NMR}(0-18 \mathrm{ppm})$, FTIR spectroscopy in the range of $(400-4000 \mathrm{~cm}-$ 1 ), powder X-rays diffraction (PXRD, $\left.2 \theta^{\circ}=10-80\right)$, Raman spectroscopy $\left(0-4000 \mathrm{~cm}^{-1}\right)$, and UV-Visible spectrophotometry $(0-800 \mathrm{~nm})$. Then the activity of these materials was investigated as a gas sensing of (Ammonia, Methanol and Acetone). For each case, $0.2 \mathrm{mg} / \mathrm{mL}$ of the prepared Copc, Copc/MWCNT, Copc/MWCNTs-MO was dispersed in $1 \mathrm{~m}$ of ammonia, methanol and acetone at 298K. The surface morphology of the prepared materials was heterogeneous.
\end{abstract}

Key words: Cobalt phthalocyanine, MWCNTs, Nanocomposite, Gas sensing

\section{Introduction:}

Multiwall carbon nanotubes (MWCNTs) were discovered in 1991 as a secondary product of fullerene preparation (1). Graphene is the simplest carbon nanotube formed of a single sheet of honeycomb arranged of carbon particles (2) Graphene is rolled up consistently into a tubular shape (3). The tube walls are made up of a hexagonal grid of carbon molecules resembling closely to the atomic planes of graphite (4). Carbon nanotubes (CNTs) are characterized as a cylinder in three dimensions content of carbon atoms, and have hybridization $\mathrm{sp}^{2}$ which is stronger than diamond with hybridization $\mathrm{sp}^{3}(5)$. CNTs are an example of nanotechnology with dimensions less than $100 \mathrm{~nm}$ $(5,6)$.

Generally, Carbon Nano Tubes are insoluble in all solvents due to solid Van-Der-Waals intelligent that firmly holds them, but chemical functionalization of CNTs may improve dissolvability in different solvents and to create novel hybrid materials possibly appropriate for diverse applications such as Catalysts, Sensors, Transistors, Membranes, Electrodes, Solar cells and Fuel cells (7). Combination of metal phthalocyanine with CNTs will have potential electrocatalytic properties (8). Metal Free Phthalocyanines $\left(\mathrm{H}_{2} \mathrm{Pc}\right)$ is an organic compound with the formula $\left(\mathrm{C}_{8} \mathrm{H}_{4} \mathrm{~N}_{2}\right) 4 \mathrm{H}_{2}$. It was discovered in 1907 by Braun and Tcherniac (9). Phthalocyanine (PC,1) (tetrabenzo tetraazo porphyrin) compounds are thermally stable and has good catalytic performance (10).

$\mathrm{Pc}$ is an aromatic macrocycle compound; the structure of Pc is very similar to porphyrins with four meso-carbons substitution in position $\alpha-\gamma$ and $\beta-\delta$ axis with four addition benzene rings and content eight nitrogen atoms (11). PCs are heterocyclic aromatic compounds, used as colorant material (12-15). They are important materials with a wide range of applications on the basis of their 
optical and electrical properties, as well as thermal stability (16). Metal phthalocyanines are prepared via the reaction of urea, metal salts, ammonium molybdate, with either NDI or phthalonitriles (phthalimide, phthalic anhydride, Phthalic acid) by different methods (8-15). Mono or binuclear metal phthalocyanines are widely used in solar cell, sensor, and light-emitting device (17). More than 70 different metal ions into the central cavity can be introduced to improve physical properties of the phthalocyanine which can be with different electrical, optical, and their thermal stability (12, 18). Phthalocyanines are the second most important class of colorant compounds $(14,15)$.

Recently, the use of Pcs has been varied which can make this material an excellent choice for several applications such as gas sensors, organic solar cells (19) and oxidative degradation of pollutants or catalysts for photo and as photosensitizers (20).

The present study describes the preparation of cobalt phthalocyanine (CoPc) and its combination as nanocomposites materials to yield (Copc/F-MWCNTs/ $\mathrm{Ni}_{3} \mathrm{O}_{4}-\mathrm{Co}_{3} \mathrm{O}_{4}$ ). Then, the synthesized composite would be investigated using different spectroscopic and analytical techniques to confirm its formation. Then the activity of this prepared composite would be investigated as a

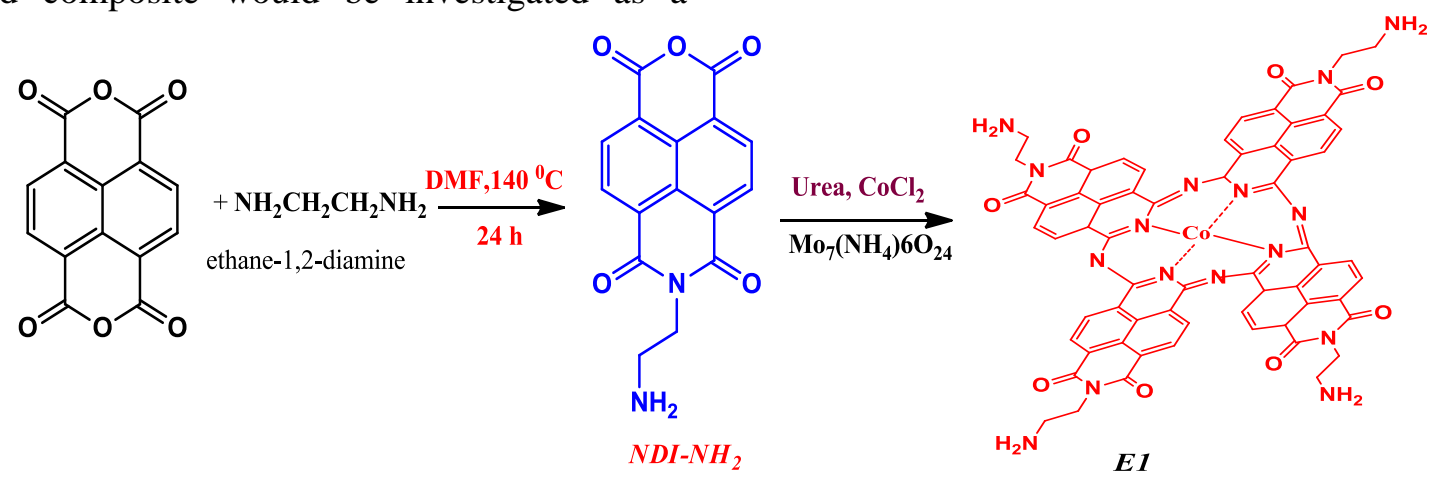

Figure 1. The preparation steps of $\operatorname{CoPc}(\mathrm{E1})$.

\section{Synthesis of Copc-MWCNTs (E2)}

In this part, $75 \mathrm{mg}$ of activated MWCNTs was dissolved in $3.5 \mathrm{~mL}$ of DMF under stirring, heating at $76^{\circ} \mathrm{C}$ and $\mathrm{N}_{2}$ flush. After that, $1 \mathrm{ml}$ of $\mathrm{SoCl}_{2}$ was added to the mixture followed by adding $0.06 \mathrm{~g}$. of sensor for probing each of ammonia $\left(\mathrm{NH}_{3}\right)$, methanol $\left(\mathrm{CH}_{3} \mathrm{OH}\right)$ and, and acetone $\left(\mathrm{CH}_{3}\right)_{2} \mathrm{CO}$. To the best of the author's knowledge, this is the first attempt to produce such composite and use it in gas sensor applications.

\section{Materials and Methods: Materials:}

MWCNTs was purchased from NanoshelUSA with a diameter of $13-18 \mathrm{~nm}$, length in the range of $1-12 \mu \mathrm{m}$, and purity $99 \%$. Naphthalene$1,4,5$, tetracarbonic acid dianhydride (NDI) $99 \%$ Alfa Aesar, co-metal oxide $\left(\mathrm{Ni}_{3} \mathrm{O}_{4}-\mathrm{Co}_{3} \mathrm{O}_{4}\right)$ (21), Dimethyl formamide (DMF, 99.5\%),Urea, Cobalt chloride $\mathrm{CoCl}_{2}$, and Ammonium molybdate $99.9 \%$ from (BDH), Thionyl chloride $\mathrm{SOCL}_{2}$, and Triethylamine $99 \%$ from (BDH).

\section{Synthesis of Compound Cobalt phthalocyanine (E1)}

(0.012g., $0.01 \mathrm{mM})$ ammonium molybdate, (3g., $50 \mathrm{mM})$ urea, $(0.756 \mathrm{~g} ., 2.6 \mathrm{mM})$ cobalt chloride and NDI-NH${ }_{2}$ were crushed together until a homogeneous powder was formed. The mixture was heated at $180^{\circ} \mathrm{C}$ for $45 \mathrm{~min}$. $(22,23)$. Figure 1 shows the preparation steps of $\mathrm{CoPc}$, which is called (E1).
CoPc after $1 \mathrm{hr}$. Finally, $1 \mathrm{~mL}$ of triethylamine was added, the final mixture was kept under reflux for $4 \mathrm{hr}$ at $110^{\circ} \mathrm{C}$ as shown in Fig.2. Then, the mixture was filtered and dried for $48 \mathrm{hr}$ at $100^{\circ} \mathrm{C}(24)$. 


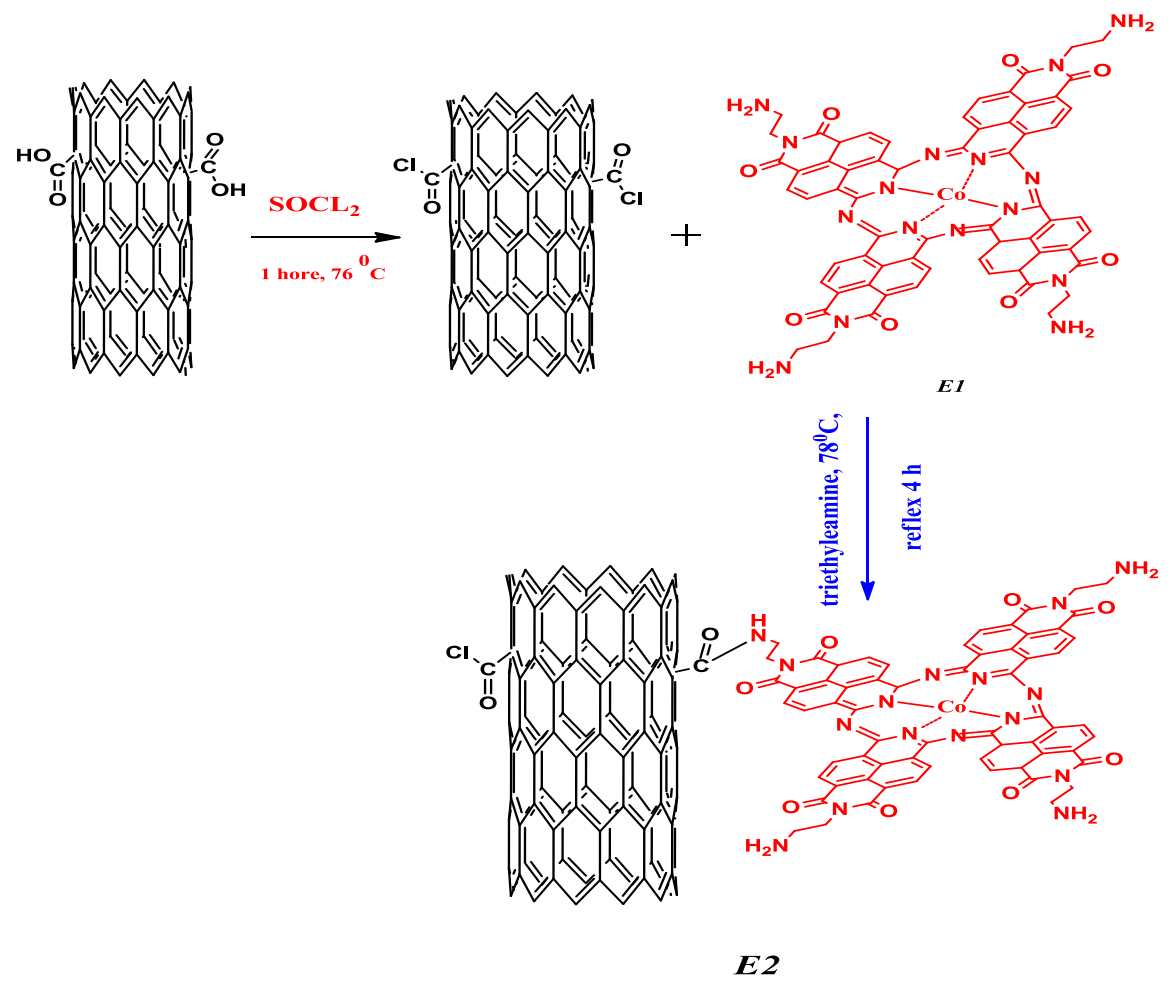

Figure 2. Synthetic steps for synthesis of CoPc/MWCNTs composite (E2).

Synthesis of Compound Copc-MWCNTs/MO nanocomposite (E3)

Nanocomposite compound was synthesized by combining E1 compound to co-metal oxide
(MO) of $\left(\mathrm{Ni}_{3} \mathrm{O}_{4}-\mathrm{Co}_{3} \mathrm{O}_{4}\right)$ and thus creating the new composite CoPc/F-MWCNTs/MO (E3) as shown in Fig.3.
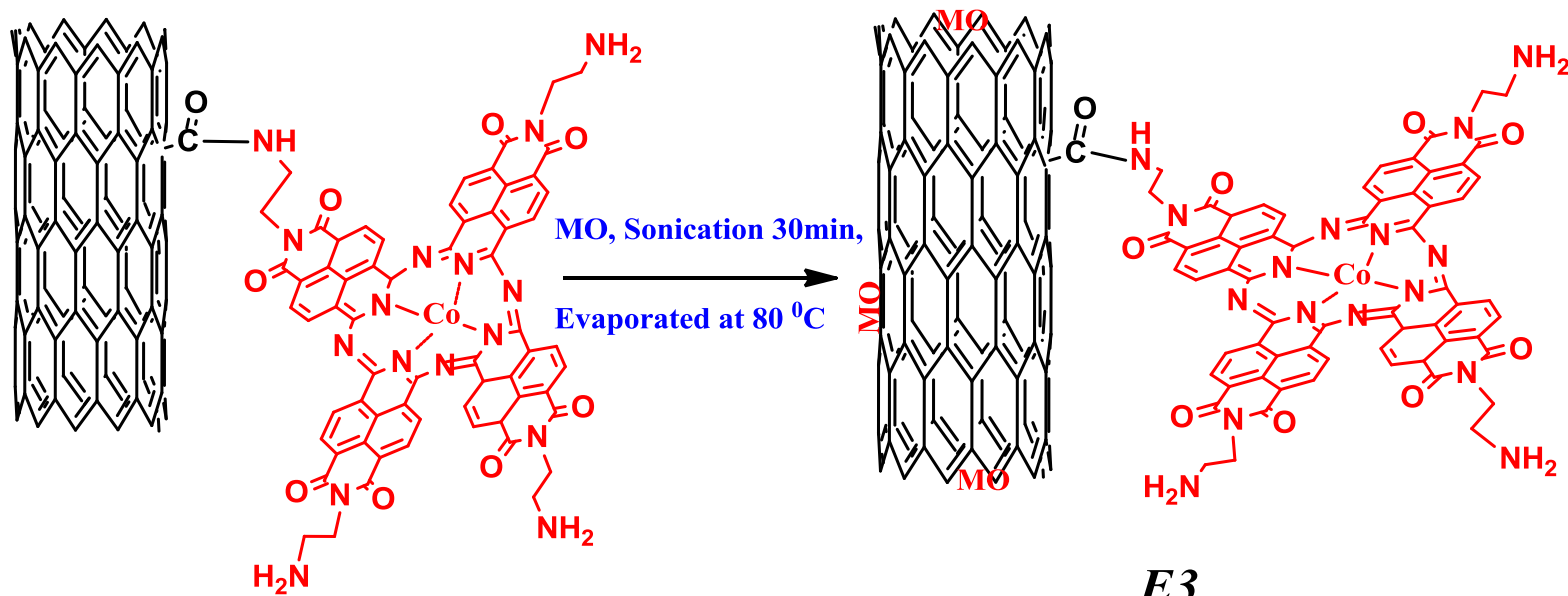

Figure 3. Schematic steps for Synthesis of CoPc/F-MWCNTs/MO (E3)

X-rays Diffraction (XRD) of the prepared materials

Crystal structure of the prepared nanocomposite was investigated using powder X-ray diffractometer, Phillips X-ray diffraction with $\mathrm{CuK} \alpha$ radiation $(1.542 \AA, 40 \mathrm{KV}, 30 \mathrm{~mA})$, in the $2 \theta$ range 10-80 degrees. XRD6000, Shimadzu, Japan.
Fourier Transform Infrared spectroscopy (FTIR)

FTIR was used to investigate functional groups on the surface of the prepared composite in the range from $400-4000 \mathrm{~cm}^{-1}$ using FTIR $8400 \mathrm{~S}$ Shimadzu Japan.

\section{Raman spectroscopy}

Raman spectroscopy was used to characterize the properties or the diameter of the tubes. Measurements were carried out at room temperature 
using SENTERRA, BRUKER-Germany, with high spatial \& spectral resolution (Spectral Resolution: < $3 \mathrm{~cm}^{-1}$ ), using laser wavenumber of $785 \mathrm{~nm}$.

\section{Gas Sensor model}

The performed studies showed using a stainless steel test chamber supported with sealed output wires for connection and a thermocouple to monitor the chamber temperature. $0.2 \mathrm{mg} / \mathrm{mL}$ of the prepared Copc, Copc/MWCNT, and Copc/MWCNTs-MO was dispersed in $1 \mathrm{~mL}$ of acetone and sonicated for $15 \mathrm{~min}$. in order to obtain a homogenous solution. Using casting method, thin films of the above solution were dried at ambient temperature. A desired concentration of ammonia, methanol and acetone were used in the chamber to determine sensing properties. Sensor resistance was recouped by opening the top of the test chamber $(25,26)$. The response of the gas sensor was calculated using the equation (1):

$$
\left.\mathrm{S}(\%)^{1 / 4}\left|\left(\mathrm{Ra}_{-} \mathrm{Rg}\right) / \mathrm{Ra}\right|_{\text {_ }} 100\right)
$$

$\mathrm{Ra}$ and $\mathrm{Rg}$ represent the sensor resistance in air and gas environment respectively.

\section{Results and Discussions: \\ FTIR Spectra for the prepared materials}

Figure 4 shows FTIR spectra of the materials under study. The starting compound $\mathrm{NDI}-\mathrm{NH}_{2}$ has demonstrated the peak $\left(\mathrm{v}, \mathrm{cm}^{-1}\right)$ : the peaks around 3545-3439 are assigned to $\left(\mathrm{NH}_{\text {aliph }}\right)$. The peaks around 3080-3207 are assigned to (C-HAr.), the peaks around 2926-2854 can be assigned to (C$\left.\mathrm{H}_{\text {aliph }}\right)$, the peak at 1707 is attributed to $\left(\mathrm{C}=\mathrm{O}_{\text {carboxylic }}\right.$ acid). The peak at 1666 is related to $\left(\mathrm{C}=\mathrm{O}_{\text {amide }}\right)$, and that at 1577.7 is related to $(\mathrm{C}=\mathrm{C} \mathrm{Ar})$. The peaks at $1320-1210$ is assigned to $(\mathrm{C}-\mathrm{O})$, and the peak at 1055 is assigned to $(\mathrm{C}-\mathrm{N})$.

On the other hand, the compound E1 has shown important peaks of phthalocyanine $\left(\mathrm{v}, \mathrm{cm}^{-1}\right)$ around 3545,3421 which is associated $\left(\mathrm{NH}_{\text {aliph }}\right)$, $3207 \quad\left(\mathrm{C}-\mathrm{H}_{\mathrm{Ar}}\right), \quad 2858-2962 \quad\left(\mathrm{C}-\mathrm{H}_{\text {alph. }}\right), \quad 1664$ $\left(\mathrm{C}=\mathrm{O}_{\text {amide }}\right), 1641(\mathrm{C}=\mathrm{N}), 1520(\mathrm{C}=\mathrm{C}),, 1344.38(\mathrm{C}-$ $\mathrm{N})$ and at $1274.95(\mathrm{C}-\mathrm{O})(25)$.
Also appearance of Co- $\mathrm{N}$ peaks around 601.77, (26). Moreover, Modification of Multiwalled Carbon Nanotubes with cobalt phthalocyanine which is compound E2 has resulted in peaks of phthalocyanine $\left(\mathrm{v}, \mathrm{cm}^{-1}\right)$, the peaks around 3392-3444 are assigned to $\left(\mathrm{NH}_{2}\right)$ group, the peaks around 2972-2937 are assigned to $\left(\mathrm{C}-\mathrm{H}_{\text {Aliph. }}\right), 3100\left(\mathrm{C}-\mathrm{H}_{\mathrm{Ar}}\right), 1707-1644(\mathrm{C}=\mathrm{O}$ amid $)$, $1471(\mathrm{C}=\mathrm{C}), 1471(\mathrm{C}-\mathrm{O}), 1396(\mathrm{C}-\mathrm{N})$, Co-N peaks at $462,731,848$ (25). Whereas compound E3 shows the peaks of F-MWCNTs/ phthalocyanine $\left(\mathrm{v}, \mathrm{cm}^{-1}\right)$ at 3404-3375 $\left(\mathrm{NH}_{2}\right), 2974\left(\mathrm{C}-\mathrm{H}_{\text {aliph }}\right), 2492\left(\mathrm{C}-\mathrm{H}_{\mathrm{Ar}}\right)$, 1697-1639 ( $\left.\mathrm{C}=\mathrm{O}_{\text {amide }}\right), 1558 \quad(\mathrm{C}=\mathrm{C}), 1400(\mathrm{C}-\mathrm{N})$, metal $(\mathrm{Co}-\mathrm{N})$ appears at $418,569(25)$.

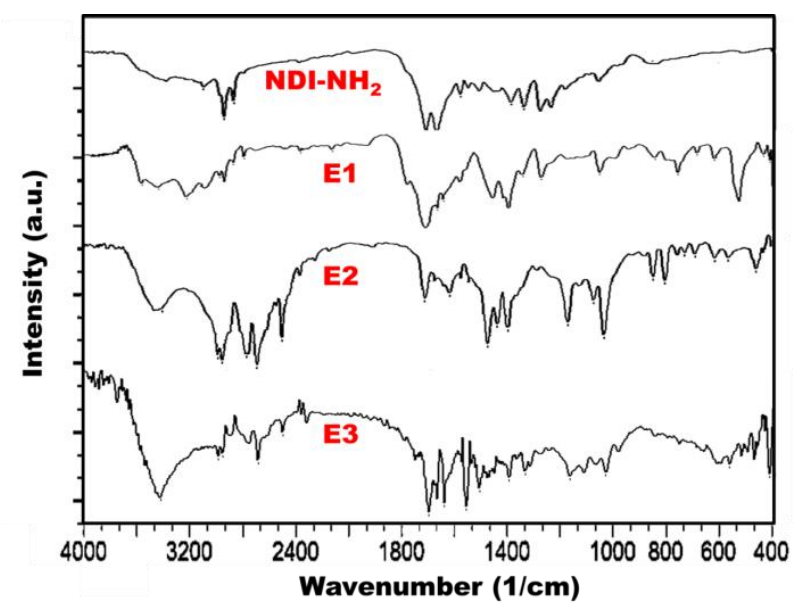

Figure 4. FTIR spectra for the prepared materials

\section{${ }^{1}$ H NMR Spectrum}

${ }^{1} \mathrm{H}$-NMR studies were carried out for the NDI$\mathrm{NH}_{2}$ and E1 compound. Figure 5 shows The ${ }^{1}$ HNMR results which indicates protons (7.9) $\mathrm{ppm}$ of (4H, Aromatic rings) and (3.6) ppm of $\mathrm{NH}_{2}$ proton, (2.1) ppm of acetone,(2.8) ppm of $\mathrm{CH}_{2}$ proton in the NDI-NH${ }_{2}$ compound. On the other hand, the E1compound exhibited protons at (8.48.8) $\mathrm{ppm}$ of $(16 \mathrm{H}$, Aromatic ring) (NDI) and (3.23.6) ppm of $\mathrm{NH}_{2}$ proton, (2.1) ppm of acetone solvent, (3) ppm $(16 \mathrm{H})$ of $\mathrm{CH}_{2}$ proton. All NMR spectra were performed at room temperature. 


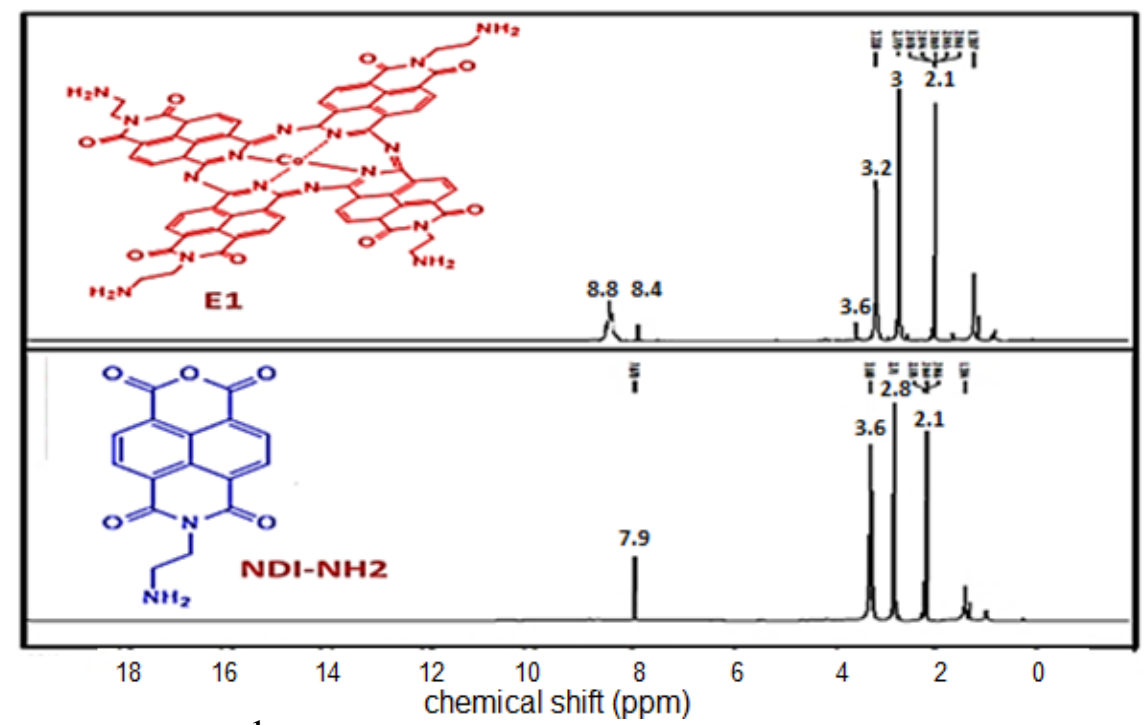

Figure 5. ${ }^{1} \mathrm{H}$ NMR spectrum of NDI-NH ${ }_{2}$ and $\mathrm{E} 1$ compounds

\section{Raman Spectra}

To investigate the interaction between $\mathrm{CoPc}$ molecules and F-MWCNTs/MO, Raman spectra have been used to evaluate the effect of adding MO to the Copc/F-MWCNTs composite as shown in Fig.6. The vibrations of isoindole moieties (27) caused the peaks at $\left(324,459,757,850,902 \mathrm{~cm}^{-1}\right)$ in CoPc sample to appear. Pyrrole groups peaks appear between $1200-1600 \mathrm{~cm}^{-1}$, while cobalt ion at $1587 \mathrm{~cm}^{-1}$, and 1571 corresponds with the previous studies $(28,29)$. Raman spectra show change in their positions and intensities. This is due to the change in the ratio of $\mathrm{sp}^{3}$ hybridized carbon atom relative to $\mathrm{sp}^{2}$ is the intensity ratio of $\mathrm{D}$ band to the $G$ band (ID/IG) valued 1.07. The changes of ID/IG value indicates that $\mathrm{CoPc}$ was linked through a non-covalent on the surface of F-MWCNTs (29). Copc/F-MWCNTs/MO composite has exhibited G-band (C-C vibration with a $\mathrm{sp}^{2}$ orbital) at 1587 , $1571 \mathrm{~cm}^{-1}$ and $\mathrm{D}$ band related to sp $\mathrm{sp}^{3} \mathrm{C}$ with flaws at $1366 \mathrm{~cm}^{-1} \mathrm{G} 2984,2976 \mathrm{~cm}^{-1}$ (29).

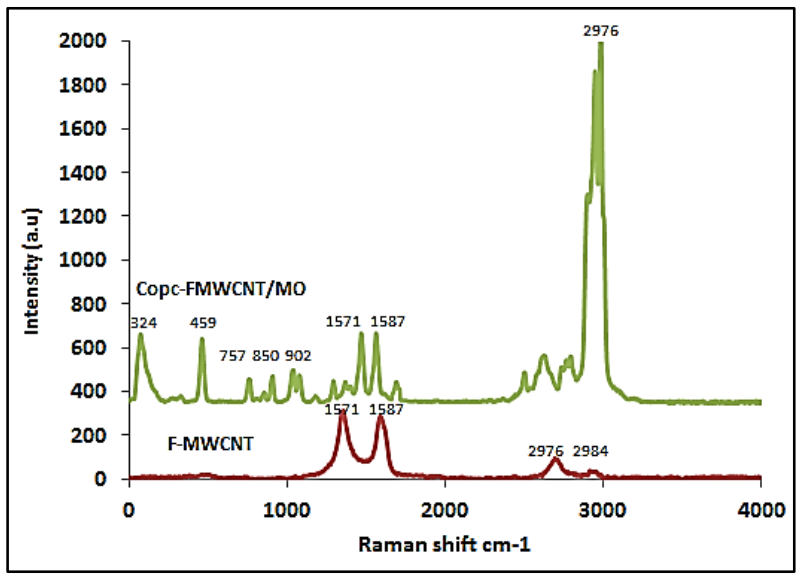

Figure 6. Raman spectrum of $\mathrm{CoPc}$ and $\mathrm{CoPc} / \mathrm{F}$ MWCNTs/MO

\section{UV-Visible spectra of NDI-NH compound $_{2}$}

Figure 7, shows Uv-Visible spectrum of compound NDI-NH${ }_{2}$, bands in UV region at 445, 379 , and $360 \mathrm{~nm}$ were appeared ( $\mathrm{B}$ band $=2.78 \mathrm{ev}$ ), while E1compound shows two important bands $(\mathrm{Q}$ band reaches to near IR region) at $669 \mathrm{~nm}(\mathrm{Q}$ band $=1.85 \mathrm{ev}$ ), and (B band=3.28 ev in $\mathrm{Uv}$ region of the spectrum) at $357-377 \mathrm{~nm}(30,31)$.

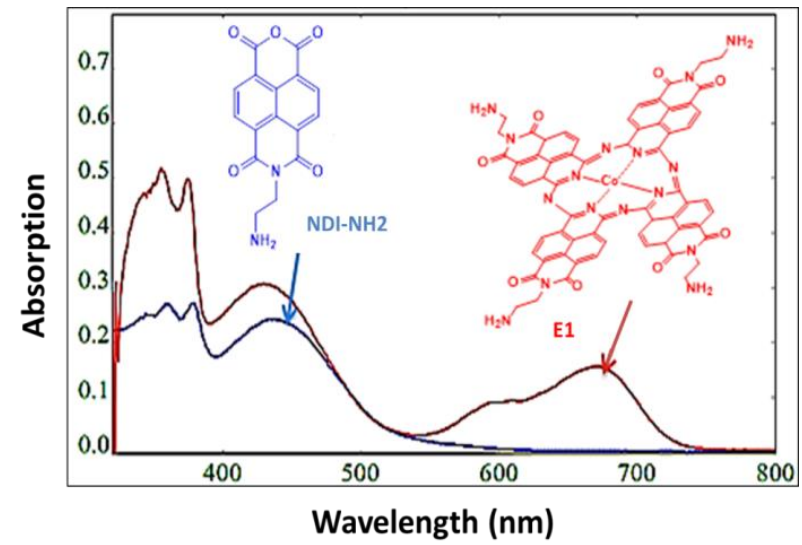

Figure7. UV-Visible of NDI- $\mathrm{NH}_{2}$ in (Blue line), and Copc (E1) (red line) in acetone conc. 1x10 ${ }^{4} \mathbf{M}$

\section{X-rays Diffraction Patterns}

XRD patterns of $\mathrm{CoPc} / \mathrm{F}-\mathrm{MWCNT}$ are shown in Fig. 8, which shows a strong intense peaks at $\left(2 \theta=12.215^{\circ}, 12.283^{\circ}, 17.538^{\circ}, 24.606\right.$ ${ }^{\circ}, 25.166^{\circ}, 26.526^{\circ}, 27.672^{\circ}, 28.081^{\circ}, 32.739^{\circ}$, $33.158^{\circ}$ ) and a low intense peak at $2 \theta=43.300^{\circ}$. These are corresponding to the F-MWCNTs, and $\beta$ Copc/F-MWCNTs. Compared to the F-MWCNTs, $2 \theta=25.20^{\circ}$ and $2 \theta=44.00^{\circ}$. These are related to the planes 002, and 102 respectively (32). In general all these peaks show a downhill shift due to mutual interaction among materials in these composites 
materials. The CoPc/F-MWCNTs/MO nanocomposites (the insert of Fig. 8) have demonstrated a shifting in peaks position when to the MO (32). At $\left(2 \theta=26.5^{\circ}, 33.69^{\circ}, 43.34^{\circ}\right)$ appears the peak for MWCNTs which are corresponding to the planes 002,111 , and 101 respectively. Also at $\left(2 \theta=24.56^{\circ}, 25.63^{\circ}, 29.64^{\circ}\right.$, $31.74^{\circ}, 33.69^{\circ}$ ) appears peak for $\mathrm{CoPc}$ when comparison with ICCD card No.44-1994 $(33,34)$.From these patterns, it is clear that both materials show crystalline structure. The broad peak that can be seen in the XRD pattern indicates the presence of graphitic structure of CNTs, which is related to the ordered arrangement of the concentric cylinders of graphitic carbon. So, this confirms the presence of the hexagonal structure of MWCNTs, which means that doping MO with Copc /F-MWCNTs does not affect significantly its crystal structure. XRD data were employed to calculate the average crystalline size (D) of the prepared material via applying Scherrers equation as shown below:

$\mathrm{D}=\mathrm{k} K / \mathrm{B} \cos \Theta$, whereas, $\mathrm{D}$ is the average crystal size, $\mathrm{k}$ is the shape factor depends on the shape of the crystal and it is equal to 0.94 for homogeneous shape and 0.89 for the heterogeneous shape.

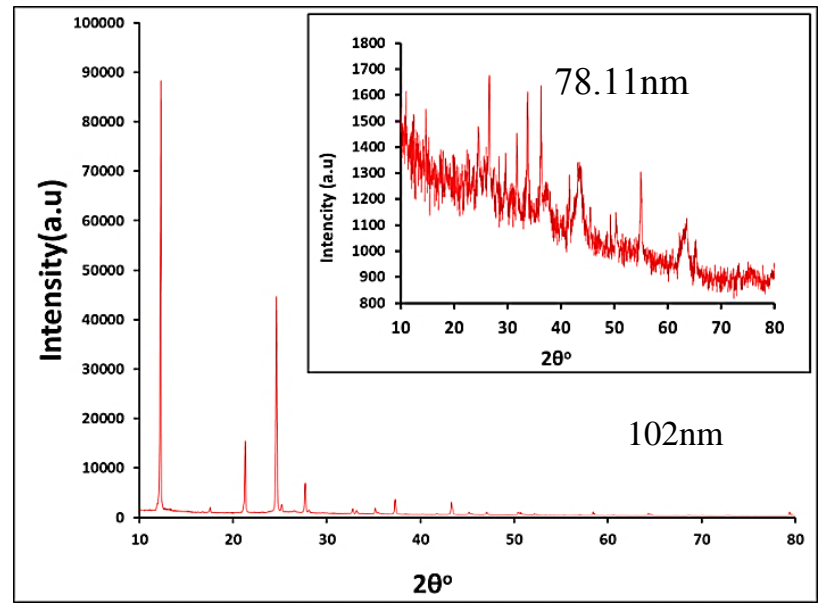

Figure 8. P XRD patterns for Copc /F-MWCNTs and the inserted represents the Copc/FMWCNTs/MO Nano composites

\section{Gas Sensing:}

CNTs are vital materials that can be utilized in sensors due to their special and curious properties, such as enormous particular surface area, gas adsorption capability and electrical conductivity. This behaviour can be shown by the sensing process that occurs on the different sites of the sensing material and thus, the performance is related to the morphology. At lower gas concentrations, the gas extends slightly on the sensor's surface zone and thus leads to a decreasing in reaction. The higher concentration of gas covers generally bigger surface area and interacts with bigger number of active destinations guiding to higher sensor reaction (34).

Reduced gasses act as electron donor when linked with metal oxide surface. Due to this interaction, these gasses desorb or evacuate the chemisorbed oxygen ions and physisorbed - $\mathrm{OH}$ ions from the MO surface. Reduced gases such as $\mathrm{NH}_{3}$, Acetone and methanol. $\mathrm{NH}_{3}$, Acetone and methanol are the foremost critical organic molecule. $\mathrm{NH}_{3}$ lone pair electrons supply strong electron acceptor conduct. It can be an electron donor to the metal oxide, when reacting with the adsorbed oxygen ions on the surface by returning the trapped electrons. Proposing free electrons mechanism was achieved via the number of oxygen ions which they react with $\mathrm{NH}_{3}$ molecules as shown in Fig. $9(33,34)$.
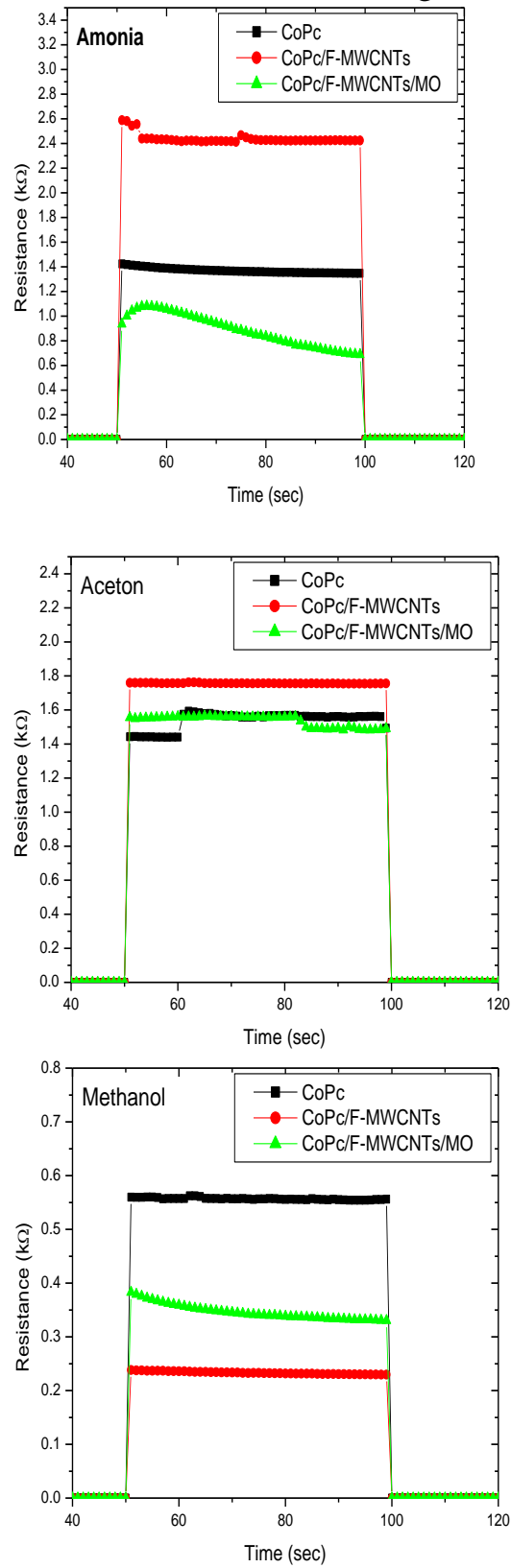

Figure 9. Gas sensing of (Ammoia, Methanol, Aceton) with Copc, Copc-F-MWCNTs, and Copc-F-MWCNTs/MO 
The lone pair of electrons of $\mathrm{NH}_{3}$ provide strong electron acceptor behavior. However, it acts as an electron donor to the surface, when reacting with the adsorbed oxygen ions on the surface by reverting the trapped electrons (35). The proposed mechanism of ammonia that generates free electrons accomplished by the number of oxygen ions reacted with $\mathrm{NH}_{3}$ molecules as shown in the equations (2-5).

$$
\begin{aligned}
& 2 \mathrm{NH}_{3}+3 \mathrm{O}_{(\text {adsorbed })}^{-} \rightarrow \mathrm{N}_{2}+3 \mathrm{H}_{2} \mathrm{O}+3 e^{-} \ldots . .2 \\
& \text { or } \\
& 4 \mathrm{NH}_{3}+3 \mathrm{O}_{(\text {adsorbed })}^{-} \rightarrow 2 \mathrm{~N}_{2}+6 \mathrm{H}_{2} \mathrm{O}+6 e^{-} \ldots .3 \\
& 2 \mathrm{NH}_{3}+4 \mathrm{O}_{(\text {adsorbed })}^{-} \rightarrow \mathrm{N}_{2} \mathrm{O}+3 \mathrm{H}_{2} \mathrm{O}+4 e^{-} \ldots .4 \\
& 2 \mathrm{NH}_{3}+5 \mathrm{O}_{(\text {adsorbed })}^{-} \rightarrow 2 \mathrm{NO}+3 \mathrm{H}_{2} \mathrm{O}+5 e^{-} \ldots . .5
\end{aligned}
$$

The time dependency of the prepared thin films based devices exhibited a reasonable stability in regard to time, upon the exposure of gas (Fig. 9). The response and recovery time, which are defined as the time it takes to reach close to the steady state and the time required to reach close to the base line respectively, were found to be different based on the gas type (with the same concentration $\approx 100 \mathrm{ppm}$ for all the different gasses) and the material under room temperature..

Generally, the gas molecules interacting with the central metal ions inside the phthalocyanine ring at the air/phthalocyanine interface leads to the formation of oxidized $\mathrm{MPc}^{+}$ and $\mathrm{O}_{2}{ }^{-}$species and injection of hole charge carriers into the thin film. This process is quite possible at the normal conditions because the change in the free Gibbs energy is negative and as a result of oxygen desorption and the released electrons change the resistance of the phthalocyanine based film (35).

\section{Conclusion:}

The nanocomposites preparation is accomplished by functionalization of CNTs with Cobalt-Phathalocyanine ( $\mathrm{CoPc})$ and co-oxide. The nano-sized tertiary system (Copc/F-MWCNTs/MO) nano composites are obtained. The avarege crystal size of the prepared materials ranges between (78102) $\mathrm{nm}$. This is evaluated using Scherres equation. These composites are investigated with XRD patterns, Raman spectroscopy, FTIR, and Uv-Vis spectroscopy. From Uv-Visible spectra, it is found that, these new compounds show strong absorptions peaks towards the NIR region between 646 and 720 $\mathrm{nm}$. Therefore, this device shows differential resistance changes, response and recovery times through exposition to $\mathrm{NB}, \mathrm{CB}$ and some other chemical vapours. The fabricated device contains transducing part from the $\mathrm{CoPc}$ functionalized MWNT-based nanocomposites. The tertiary system is employed to fabricate sensitive sensors for detection of vapour of $\mathrm{NH}_{3}$, methanol, and acetone.

\section{Authors' declaration:}

- Conflicts of Interest: None.

- We hereby confirm that all the Figures and Tables in the manuscript are mine ours. Besides, the Figures and images, which are not mine ours, have been given the permission for republication attached with the manuscript.

- Ethical Clearance: the local ethical committee in University of Babylon approved the project.

\section{References:}

1. Le PY, Cameron S, Joseph S. Recent development of carbon nanotube transparent conductive films. Chem Rev. 2016; 116 (22):13413-13453.

2. Moore VC, Strano MS, Haroz EH, Robert HH, Richard ES. Individually suspended single-walled carbon nanotubes in various surfactants. Nano Lett. 2003; 3(10) :1379-1382.

3. Ishibashi A, Nakashima N. Individual dissolution of single-walled carbon nanotubes in aqueous solutions of steroid or sugar compounds and their raman and near-IR spectral properties. Chem Eur J. 2006; 12(29):7595-7602.

4. Lin T, Bajpai V, Ji T, Dai L. Chemistry of carbon nanotubes. Aust J Chem. 2003; 56(7) :635-651.

5. Kevin C, Segi B, Jaemyung K, Jiaxing H. Additivefree carbon nanotube dispersions, pastes، gels, and doughs in cresols. PNAS. 2018; 115(22) :5703-5708.

6. Lili J, Yimin M, Sihao T,Yuanshou Z, Qi C, Wenpeng Z, Haitao Y, Xingang H. Graphene Oxide/Single-Walled Carbon Nanotube Membranes for $\mathrm{CO}_{2}$ and $\mathrm{N}_{2}$ Separation from Blast Furnace Gas. $\mathrm{J}$ Nanomater. 2020; 2020(4):1-15.

7. Chuanyin X, Tiehu L, Yechuan Z, Tingkai Z, Alei D, Xianglin J,Hao L, Jungao W. Two-step approach of fabrication of three dimensional reduced graphene oxide-carbon nanotubes-nickel foams hybrid as a binder-free supercapacitor electrode. Electrochim Acta. 2016; 217(31) :9-15.

8. Maizlish VE, Tikhomirova TV, Znoiko SA, Aleksandriiskii VV, Vashurin AS, Shaposhnikov GP. Synthesis and Properties of Tetra(4-tert-butyl-5phenylsulfanyl)phthalocyanines and Their Derivatives. Russ J Gen Chem. 2018; 88(4):736-741.

9. Kieran N, dulli B, Topuz B, Gungor G, Bora M, Uner C. Synthesis and characterization of copper phthalocyanine and tetracarboxamide copper phthalocyanine deposited mica-titania pigments. Dyes Pigm. 2013; 96(1):31-37.

10. Sekailana T. Characterization and application of phthalocyanine-gold nanoparticle conjugates. MSc thesis. Grahamstown, South Africa: Rhodes University; 2013. 
11. Leznof fCC, Lever ABP. Phthalocyanines: Properties and Applications. 4th ed.VCH Publishers (LSK) Ltd. Cambridge; 1989.

12. Linstead RPJ. phthalocyanines. Part I. A new type of synthetic colouring matters. J Chem Soc. 1934;1(0): 1016-1017.

13. Venkataraman K. The Chemistry of Synthetic Dyes. Academic Press Inc. Angew Chem.1953;65(13)359360.

14. Kadish K, Smith KM, Guilard R, editors. The porphyrin handbook: phthalocyanines: properties and materials. Elsevier; 2000.

15. Sumana K, Chadinee T, Thara S. Development of Organic-Inorganic Hybrid Optical Gas Sensors for the Non-Invasive Monitoring of Pathogenic Bacteria. Sensors. 2018; 18(10):3189.

16. Esra K, Nurcan G, Ahmet A, Bekir S,Özer B. Synthesis, characterization and VOCs adsorption kinetics of diethylstilbestrol-substituted metallo phthalocyanines. JPP. 2019; 23 (01n02) : 166-174.

17. Boyle RW, Rousseu J, Kudrevich SV, Ohochi MOK, Lier JE. Hexadecafluorinated zinc phthalocyanine: photodynamic properties against the EMT-6 tumour in mice and pharmacokinetics using $65 \mathrm{Zn}$ as a radiotracer. Fluorinated zinc phthalocyanine. $\mathrm{Br} \mathrm{J}$ Cancer. 1996; 73(1): 49-53.

18. Nasir EM, Hussein MT, Al-Aarajiy AH. Impact Thickness Structural and Electrical Characterization of Nickel Phthalocyanine Thin Films. AMPC. 2019; 9(7): 123-132.

19. ZhiJiang G, Bin W, Xiaolin W, Yong L, Shijie G,Yiqun W. A high-sensitive room temperature gas sensor based on cobalt phthalocyanines and reduced graphene oxide nanohybrids for the ppb-levels of ammonia detection. RSC Adv. 2019; 9(64): 3751837525.

20. Nasir EM, Hussein MT, Al-Aarajiy AH. Investigation of Nickel Phthalocyanine Thin Films for Solar Cell Applications. AMPC. 2019; 9(8):158-173.

21. Mohammed HA, Kareem MM. Synthesis and Characterization of New Zinc-phthalocyanine with Four Dodecenyl-benzoic Pendant Groups. JUBPAS. 2017; 25(2):420-415.

22. Hejun Li, Zhanwei Xu, Kezhi Li, Xianghui H, Gaoxiang C, Qinglin Z, Zeyuan C. Modification of multi-walled carbon nanotubes with cobalt phthalocyanine: effects of the templates on the assemblies. J Mater Chem. 2011; 21(4): 1181-1186.

23. Jia L, Yujiang S, Gaixia Z, Huiyuan L, Yiren W, Shuhui S, Xinwen G. Pyrolysis of Self-Assembled Iron Porphyrin on Carbon Black as Core/Shell Structured Electrocatalysts for Highly Efficient Oxygen Reduction in Both Alkaline and Acidic Medium, Adv Funct Mater. 2017; 27(3):1-10.

24. Serkan A, Derya T, Devrim A,Vefa A, Javed HN, Fabienne D. Zn phthalocyanine conjugation to H2-ul aptamer for HER2-targeted breast cancer photodynamic therapy: Design, optimization and properties, JPP. 2017; 21(2): 887-892.

25. Wang Y, Nantao H, Zhihua Z, Dong X, Zi W, Zhi Y., Hao W, Eric SWK, Yafei Z. Single-walled carbon nanotube /cobalt phthalocyanine derivative hybrid material: preparation, characterization and its gas sensing properties. J Mater Chem. 2011; 21(11): 3779-3787.

26. Abbas JA, Salih HK, Emman JM. Photocatalytic Removal of Bismarck Brown $\mathrm{G}$ and Reactive Yellow 145 over Prepared $(\mathrm{Co}, \mathrm{Ni})_{3} \mathrm{O}_{4}$ Spinel Catalyst. Indian J Sci Technol. 2016; 9(17): 998-999.

27. Hongsa H, Ziwei C, Yunlong Z, Jiaqi Q, Yujiang S. Ionic self-assembly of metalloporphyrin /heteropolyacid on multi-wall carbon nanotubes with enhanced electrocatalytic activity toward oxygen reduction reaction. JPP. 2019; 23(3): 235-242.

28. Fangxin L, Yangong Z, Changzhou H, Jiawen J. Gas Sensing by Microwave Transduction: Review of Progress and Challenges. Front Mater. 2019; 6(101):1-12

29. Amel S, Allal L, Mohamed CB. Conductivity modeling of gas sensors based on copper phthalocyanine thin films. Rev Sci Technol Synthèse .2017;23(1) : $18-27$.

30. Alexander GM, Olga C, Sergei AK, Ilya AM, Ekatherina ER, Alexander VL, Sreetama B, Georgeta S., Dietrich RTZ. Nanoantenna-assisted plasmonic enhancement of IR absorption of vibrational modes of organic molecules. BJN. 2017; 8(3): 975-981.

31. Norazlina S, Dess IMZ, Fauzan A, Hazlihan H, Muhammad TA, Anas AL, Harith A, Kaharudin D, Sulaiman WH. Q-switched thulium-doped fibre laser operating at $1900 \mathrm{~nm}$ using multi-walled carbon nanotubes saturable absorber. J Eng. 2014 ;2014 (6) 297-301.

32. Dejun W, Rui G, Shuaijun W, Fang L, Yongqiang W, Chaocheng Z. Synthesis and characterization of cobalt phthalocyanine/MCM-41 and its photocatalytic activity on methyl orange under visible light. DWT. 2016; 57(52): 1-9.

33. Zhao ZH, Fan JM, Xie MM, Wang ZZ. Photocatalytic reduction of carbon dioxide with in-situ synthesized $\mathrm{CoPc} / \mathrm{TiO}_{2}$ under visible light irradiation. J Cleaner Prod. 2009;17(11): 1025-1029.

34. Jareena BJH, Sarathbavan M, Gabriele M، Venkatramaiah N, Surya VJ. Development of Gas Sensor Array based on Phthalocyanines Functionalized $\mathrm{TiO}_{2} / \mathrm{ZnO}$ Heterojunction Thin Films. Proceedings 2018; 2(13): 1042.

35.Parkhomenko RG, Sukhikh AS, Klyamer DD, Krasnov PO, Gromilov S, Kadem B, Aseel KH, Tamara VB.Thin films of unsubstituted and fluorinated palladium phthalocyanines: Structure and sensor response towards ammonia and hydrogen. J Phys Chem C. 2017; 121(2): 1200-1209. 
تحضيز وتثخيص وتطبيق متحس للغاز لمركب جديد من انابيب الكاريون النانوية: الفثالوسيانين:أوكسيد الفلز

عباس جاسم عطيه1

ايمان جاسم محمد 1

براق يحيى كاظم²

مهند موسى كريم1

1 2 الكسم الكيمياء، كلية العلوم، جامعة بابل، بابل، العر اق.

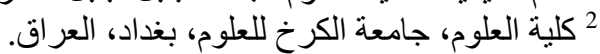

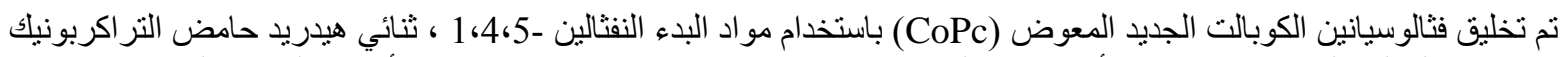

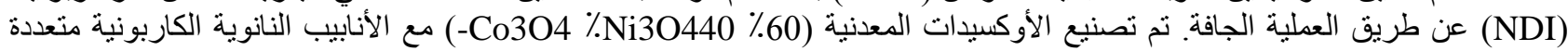

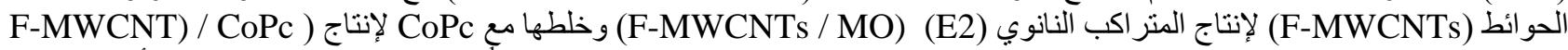

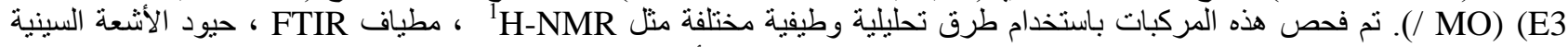

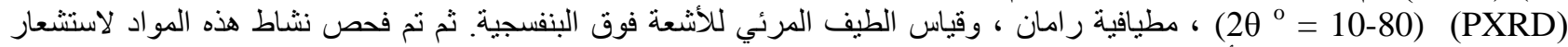

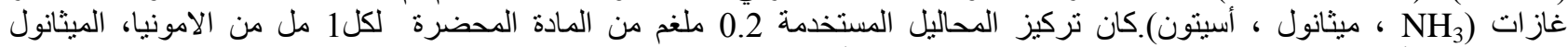
و الاسيتون. تم أجر اء القياسات بدرجة حرارة 298 كلفن. كانت الأشكال السطحية للمو اد المحضرة غير متجانسة. الكلمات المفتاحية: الكوبالت فثالوسيانين ,انابيب الكاربون النانوية ، مو اد مركّبة نانوية، استشعار الغاز. 